\title{
PREFERENSI PEDESTRIAN DITINJAU DARI PENGGUNAAN TROTOAR DI KORIDOR JALAN PEMUDA KOTA MAGELANG
}

\author{
Iwan Priyoga \\ Universitas Pandanaran \\ Jl. Banjarsari Barat No. 1, Pedalangan, Banyumanik, Semarang \\ masiw_pr@yahoo.com
}

\begin{abstract}
Sidewalk is a public space that is enabled for the convenience of pedestrians in the activity of walking from one place to another. Required a separate room that functioned as pedestrian paths. Sidewalks along the corridor Jalan Pemuda in Magelang City has an interesting phenomenon that the sidewalk on the east side grows activities that are not integrated and coordinated. The existence in the form of street vendors, tricycles, bicycles and even motorcycles utilize the sidewalk as the circulation path to make the condition of the pavement on the east side become irregular and interfere with pedestrians as users. While the condition of the pavement on the west side of the corridor Jalan Pemuda in Magelang City has relatively little interference as well as a sidewalk on the east side. This research was conducted to reveal the extent to which preferences utilizing pavement pedestrians to walk along the sidewalk. This phenomenon is interesting to study because it is associated with the option of pedestrians using the sidewalk as the movement path of circulation. This research is based on qualitative rationalistic approach. Rationalistic qualitative research approach is consistent with the nature of the research problem is to uncover the factors that influence the choice and pedestrian in exploiting the sidewalk along the road corridor Jalan Pemuda in Magelang City.
\end{abstract}

Keywords: preferences. pedestrian, sidewalk

\begin{abstract}
Abstrak
Trotoar (jalur pedestrian) adalah ruang publik kota yang difungsikan untuk kenyamanan pejalan kaki dalam aktivitas berjalan dari satu tempat ke tempat yang lain. Diperlukan suatu ruang tersendiri yang difungsikan sebagai jalur pejalan kaki. Trotoar di sepanjang koridor Jalan Pemuda Kota Magelang memiliki fenomena yang menarik yaitu trotoar di sisi timur tumbuh aktifitas yang tidak terintegrasi dan terkoordinasi. Keberadaan berupa pedagang kaki lima (PKL), becak, sepeda bahkan sepeda motor memanfaatkan trotoar sebagai jalur sirkulasi membuat kondisi trotoar di sisi timur menjadi tidak teratur dan mengganggu kenyamanan pejalan kaki sebagai pengguna. Sedangkan kondisi trotoar di sisi barat koridor Jalan Pemuda Kota Magelang relatif tidak memiliki gangguan seperti halnya trotoar di sisi timur. Penelitian ini dilakukan untuk mengungkap sejauh mana preferensi pejalan kaki dalam memanfaatkan trotoar untuk berjalan kaki di sepanjang trotoar tersebut. Fenomena inilah yang menarik untuk diteliti karena terkait dengan pilihan dari pejalan kaki dalam menggunakan trotoar sebagai jalur pergerakan sirkulasinya. Penelitian ini dilakukan berdasarkan pendekatan kualitatif rasionalistik. Pendekatan penelitian kualitatif rasionalistik ini sesuai dengan sifat masalah penelitian yaitu untuk mengungkap faktor-faktor yang mempengaruhi dan menjadi pilihan pejalan kaki (pedestrian) dalam memanfaatkan trotoar disepanjang koridor Jalan Pemuda Kota Magelang.
\end{abstract}

Kata kunci: preferensi. pedestrian, trotoar 


\section{PENDAHULUAN}

Kota merupakan suatu tatanan fisik spasial yang terbentuk oleh elemen-elemen fisik yang saling mempengaruhi, antara lain bangunan, pohon, jalan, jalur pedestrian dan tamantaman kota, kesemuanya itu merupakan elemen-elemen pembentuk kota yang akan selalu berkembang dari waktu ke waktu.

Trotoar (jalur pedestrian) adalah ruang publik kota yang difungsikan untuk kenyamanan pejalan kaki dalam aktivitas berjalan dari satu tempat ke tempat yang lain. Oleh karenanya diperlukan suatu ruang tersendiri yang difungsikan sebagai jalur pejalan kaki. Ruang jalur pejalan kaki dalam ruang publik kota menjadi begitu diperhatikan akhir-akhir ini karena banyak pihak mulai merasakan perlunya suatu ruang luar bangunan yang tidak hanya berfungsi sebagai penghubung (link) antar bangunan saja, tetapi juga dapat memiliki nilai lebih nilainya sebagai sebuah tempat beraktivitas. Dalam perencanaan kota, trotoar sebagai fasilitas pejalan kaki harus dipertimbangkan karena merupakan bagian dari elemen urban desain (Shirvani, 1985). Jalur pedestrian (pedestrian ways), merupakan jalur jalan khusus tempat orang dapat berjalan kaki tanpa menggunakan kendaraan (Shirvani, 1985).

Seiring dengan munculnya beberapa toko retail besar (supermarket) di sekitar Alunalun, menjadikan kawasan koridor Jalan Pemuda Kota Magelang memiliki magnet baru di ujung utaranya. Pasar Rejowinangun sebagai pasar tradisional terbesar di Kota Magelang merupakan magnet di ujung selatan koridor Jalan Pemuda tersebut, hal ini membuat pergerakan manusia (sirkulasi) di koridor tersebut menjadi semakin banyak dan ramai.

Fasilitas sirkulasi utama bagi pejalan kaki di koridor Jalan Pemuda Kota Magelang berupa trotoar yang membentang disepanjang pertokoan di sisi kanan dan kiri Jalan Pemuda. Trotoar ini difungsikan untuk memberikan aktivitas, aksesbilitas, kenyamanan, keamanan dan visibilitas bagi pejalan kaki sebagai pengguna supaya pengunjung di kawasan Pecinan di Jalan Pemuda dapat berjalan dari ujung yang satu (Alun-alun) ke ujung yang lain (Pasar Rejowinangun) untuk berbelanja di kawasan perdagangan tersebut.

Kondisi eksisting trotoar di koridor Jalan Pemuda Kota Magelang memiliki lebar yang berbeda, trotoar di sisi sebelah timur dengan lebar 6,00 meter, sedangkan trotoar di sisi sebelah barat memiliki lebar 2,30 meter. Perbedaan lebar trotoar yang cukup besar antara ruas trotoar di sisi timur dan barat memunculkan fenomena pada aktivitas yang terjadi didalamnya. Pada trotoar di sisi timur tumbuh aktivitas yang tidak terintegrasi dan terkoordinasi. Keberadaan berupa pedagang kaki lima (PKL), becak, sepeda bahkan sepeda motor memanfaatkan trotoar sebagai jalur sirkulasi membuat kondisi trotoar di sisi timur menjadi tidak teratur dan mengganggu kenyamanan pejalan kaki sebagai pengguna. Sedangkan kondisi trotoar di sisi barat koridor Jalan Pemuda Kota Magelang relatif tidak memiliki gangguan seperti halnya trotoar di sisi timur.
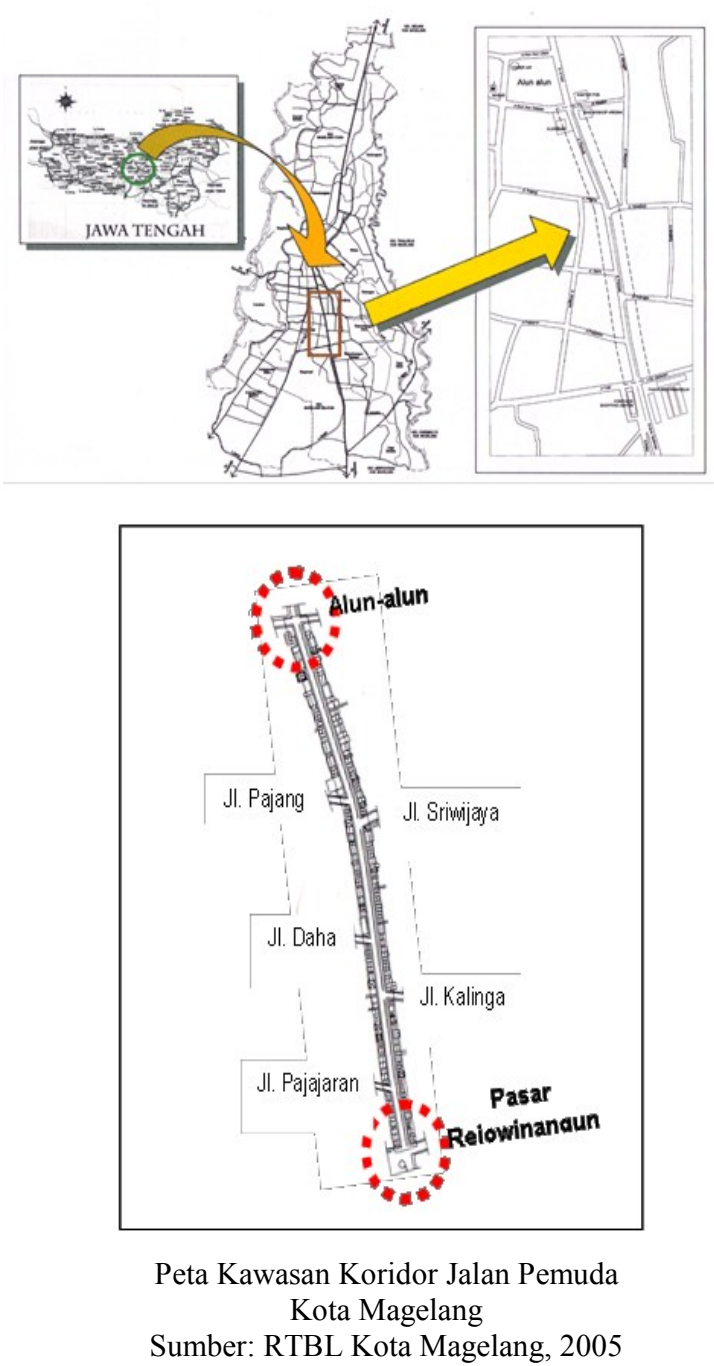
Dari hasil observasi awal yang telah dilakukan di lokasi penelitian, sepanjang koridor Jalan Pemuda Kota Magelang, ditemukan fenomena adanya perbedaan pemanfaatan trotoar, bahwa pejalan kaki lebih banyak menggunakan trotoar sisi sebelah timur daripada di sisi sebelah barat, meskipun trotoar di sisi sebelah timur penuh dengan gangguan kenyamanan bagi pejalan kaki.

Tujuan dari penelitian ini adalah untuk mengetahui: preferensi pedestrian dalam penggunaan trotoar di koridor Jalan Pemuda Kota Magelang. Manfaat dengan dilaksanakannya studi ini adalah:

1. Sebagai dasar pijakan untuk dapat dikembangkan dan dimanfaatkan sebagai penelitian lebih lanjut yang berkaitan dengan materi penelitian.

2. Penelitian ini dapat dipergunakan sebagai bahan pertimbangan oleh Pemerintah Kota Magelang dalam merencanakan dan merancang fasilitas serta kualitas trotoar di koridor Jalan Pemuda Kota Magelang.

\section{METODE PENELITIAN}

Metode penelitian pada penelitian ini dilakukan berdasarkan pendekatan kualitatif rasionalistik, pada pendekatan ini dilakukan dengan cara pendekatan investigasi karena peneliti mengumpulkan data dengan cara bertatap muka langsung dan berinteraksi dengan orang-orang di tempat studi (McMillan \& Schumacher, 2003). Pendekatan kualitatif rasionalistik ini sesuai dengan sifat masalah studi yaitu untuk mengungkap faktorfaktor yang mempengaruhi dan menjadi pilihan pejalan kaki (pedestrian) dalam memanfaatkan trotoar disepanjang koridor Jalan Pemuda Kota Magelang.

Analisis data penelitian dilakukan secara induktif, grounded theory. Pendekatan kualitatif menggunakan analisis data secara induktif dengan alasan:

1. Proses analisis secara induktif lebih cepat menemukan kenyataan-kenyataan ganda dalam data;

2. Analisis induktif lebih dapat membuat hubungan antara peneliti dan responden menjadi eksplisit, dikenal dan akuntabel;

3. Analisis induktif lebih dapat menguraikan latar alamiah secara penuh dan dapat membuat keputusan-keputusan tentang dapat tidaknya mengalihkan analisis tersebut pada suatu latar lainnya;
4. Analisis induktif lebih dapat menemukan pengaruh bersama yang mempertajam hubungan antar konsep, dan juga dapat memperhitungkan nilai-nilai secara eksplisit sebagai bagian dari struktur analistik.

\section{HASIL DAN PEMBAHASAN}

\section{Kondisi Dan Potensi Koridor Jalan Pemuda Kota Magelang}

Berdasarkan pengamatan ada fenomena yang menarik dari perilaku para pejalan kaki dalam memanfaatkan trotoar di sepanjang koridor Jalan Pemuda Kota Magelang tersebut, yaitu para pejalan kaki (pedestrian) lebih banyak memanfaatkan trotoar di sisi sebelah timur meskipun dengan kondisi yang penuh ketidaknyamanan serta membahayakan bagi pejalan kaki dalam melakukan aktivitasnya berjalan disepanjang trotoar tersebut. Kondisi eksisting permukaan trotoar di sisi timur yang cenderung licin dengan finishing material dari keramik, banyaknya lalu-lalang pengguna sepeda maupun sepeda motor yang memanfaatkan trotoar, maupun pedagang kaki lima (PKL) yang banyak menempati dan menempel di depan pertokoan di sepanjang trotoar. Meskipun dengan kondisi tersebut pejalan kaki tidak banyak memanfaatkan trotoar di sisi sebelah barat yang relatif sepi dan aman, dengan material finishing trotoar dari paving block yang kasar dan tidak licin, tidak terganggu oleh lalulalang pengguna sepeda maupun sepeda motor serta minim pedagang kaki lima. Fenomena inilah yang menarik untuk diteliti karena terkait dengan perilaku pejalan kaki.

Fenomena ini menjadi semakin menarik karena trotoar di sisi timur koridor Jalan Pemuda cenderung lebih banyak dimanfaatkan pejalan kaki sepanjang hari dari pagi hari sampai malam hari, dan melihat lintasan matahari dari timur ke barat yang akibatnya panas matahari sore yang langsung mengenai trotoar sisi timur koridor Jalan Pemuda.

Penelitian akan dilakukan untuk mengungkap perilaku pengguna, dalam hal ini adalah pejalan kaki, dalam memanfaatkan trotoar di koridor Jalan Pemuda Kota Magelang tersebut. Karena perkembangan suatu koridor dapat dilihat dari pengelolaan sebuah koridor jalan, yang berkaitan erat dengan faktor fisik dan non fisik yang ada di sekeliling koridor jalan tersebut. 
Fenomena di atas sangat berkaitan perilaku pejalan kaki terhadap pemilihan dalam menggunakan trotoar. Pemilihan (preferensi) faktor kenyamanan terhadap penggunaan trotoar sebagai jalur sirkulasinya merupakan salah satu hal terpenting dalam alasan mengapa seseorang lebih memilih trotoar di sisi sebelah timur meskipun banyak hal yang mengganggu aktivitas pergerakan sirkulasinya dalam berjalan kaki.

Koridor Jalan Pemuda Kota Magelang menjadi kawasan pusat perdagangan dan penghubung Alun-alun kota dengan Pasar Rejowinangun. Deretan pertokoan, minimarket, restoran menjadi daya tarik pengunjung dalam memanfaatkan koridor ini. Jalur pedestrian yang berada disepanjang koridor menjadi media sirkulasi bagi pejalan kaki untuk beraktifitas.

Jalur pedestrian (trotoar) disisi timur yang cenderung lebih lebar daripada di sebelah barat, ditambah dengan adanya vegetasi berupa pohon-pohon besar yang berfungsi sebagai peneduh sepanjang jalur pedestrian (trotar) sisi sebelah timur. Kondisi jalur pedestrian (trotoar) sisi sebelah barat yang lebih sempit dan berada disisi dimana kendaraan berjalan cepat dijalur sebelah kanan, ditambah dengan kurangnya vegetasi pohon peneduh.

Dari hasil pengamatan di lokasi Studi, ditemukan kondisi dan potensi yang ada pada masing-masing trotoar, yaitu:

1. Trotoar sebelah Timur

a. Memiliki properti yang lengkap untuk mendukung aksesbilitas, keamanan dan kenyamanan bagi pejalan kaki, antara lain: vegetasi (pohon) peneduh, lampu penerang trotoar, sitting group, tempat sampah;

b. Memiliki lebar trotoar 6.00 meter;

c. Memiliki permukaan trotoar yang rata dari ujung utara ke selatan, kecuali pada persimpangan jalan;

d. Trotoar tidak langsung berdampingan dengan jalur cepat Jalan Pemuda, karena dibatasi oleh tempat parkir disepanjang koridor;

e. Trotoar terbuat dari material keramik eksterior (keramik kasar);

f. Trotoar juga dimanfaatkan oleh pengguna yang lain, yaitu: sepeda, becak, sepeda motor maupun pedagang kaki lima (PKL).
2. Trotoar sebelah Barat

a. Tidak memiliki properti selengkap di trotoar sebelah timur, vegetasi yang ada hanya berupa tanaman dalam pot;

b. Lebar trotoar 2,30 meter;

c. Memiliki permukaan trotoar yang rata dari ujung utara ke selatan, kecuali pada persimpangan jalan;

d. Trotoar terbuat dari paving block;

e. Langsung berdampingan dengan jalur cepat kendaraan.
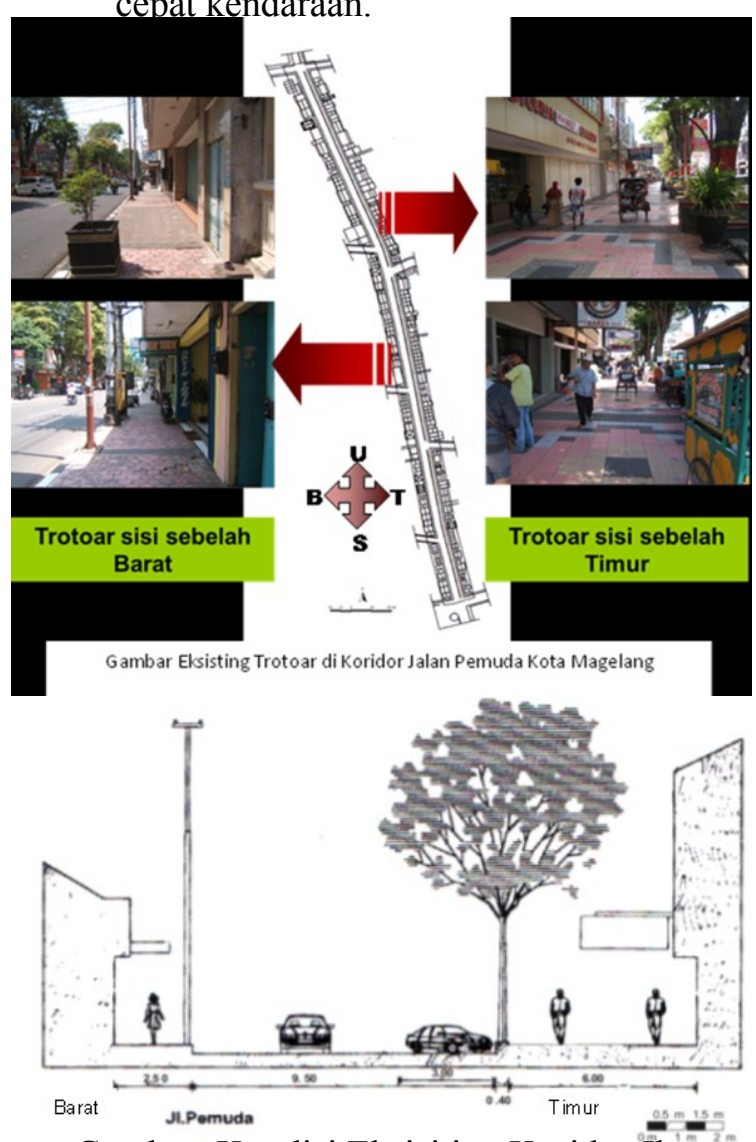

Gambar. Kondisi Eksisiting Koridor Jl

Pemuda Kota Magelang

Sumber: Hasil Survey

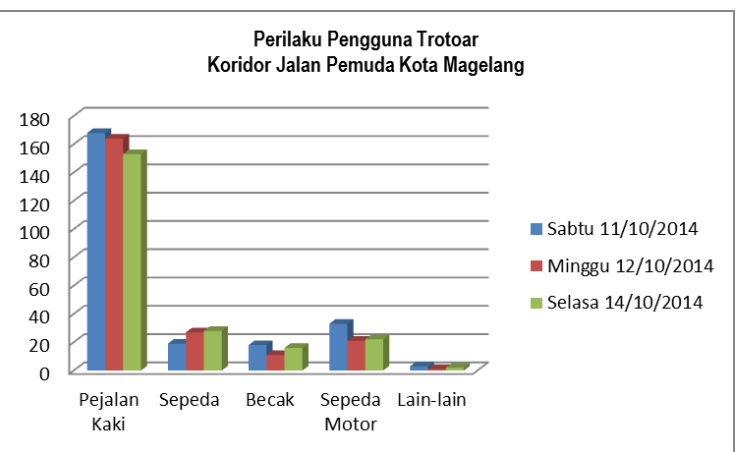

Gambar Diagram Perilaku Pengguna Trotoar Di Koridor Jl. Pemuda Kota Magelang Sumber: Hasil Survey 


\section{Motivasi Pedestrian (Pejalan Kaki) Dalam Penggunaan Trotoar}

Pejalan kaki dalam melakukan aktivitasnya berjalan di koridor Jalan Pemuda Kota Magelang memiliki motif sendiri-sendiri tergantung kebutuhan yang akan mereka lakukan di koridor tersebut. Banyak motif yang muncul dari masing-masing pejalan kaki berkaitan dengan pergerakan sirkulasi yang dilakukan sepanjang trotoar di koridor Jalan Pemuda Kota Magelang.

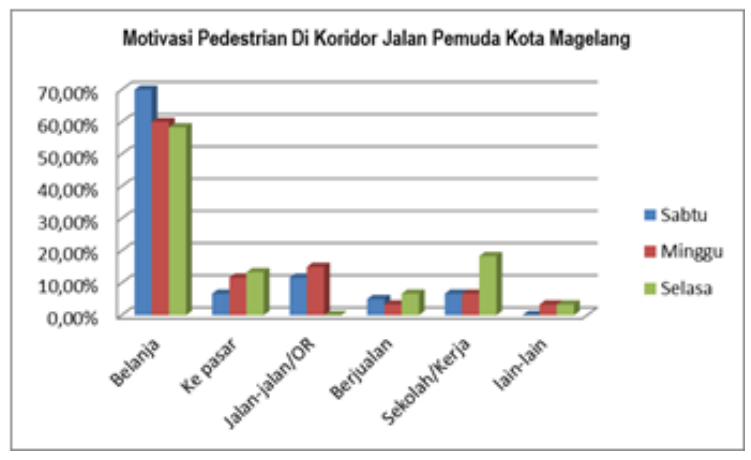

Gambar Diagram Motivasi Pedestrian (Pejalan Kaki) Di Koridor Jl. Pemuda Kota Magelang Sumber: Hasil Survey

Dari hasil Studi dilakukan pada 3 (tiga) hari pemgamatan, ditemukan pola perilaku pejalan kaki dalam melakukan aktivitas di koridor Jalan Pemuda Kota Magelang, sebagai berikut:

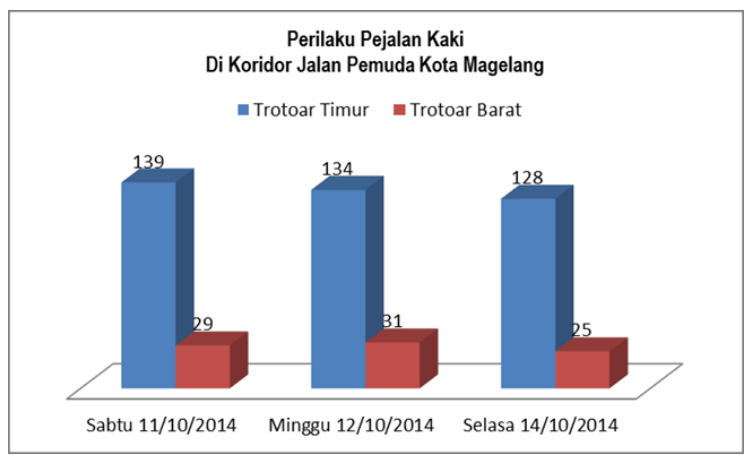

Gambar Diagram Perilaku Pejalan Kaki Di Koridor Jl. Pemuda Kota Magelang Sumber: Hasil Survey

Pengamatan menunjukkan bahwa pola perilaku pejalan kaki lebih banyak menggunakan trotoar di sebelah timur untuk beraktivitas dalam melakukan pergerakan sirkulasinya pada setiap hari pengamatan, dengan perbandingan rata-rata $80 \%$ pejalan kaki memilih di trotoar sebelah timur dan $20 \%$ pejalan kaki memilih berjalan di sebelah barat.

\section{Tanggapan Pedestrian Terhadap Trotoar Sebelah Timur Yang Dilewati}

Tanggapan Pedestrian (pejalan kaki) terhadap trotoar sebelah timur yang dlewati menunjukkan bahwa:

- Pedestrian (pejalan kaki) memilih kondisi trotoar yang bersih dan rapi, lebar serta nyaman terhadap jalur pedestrian yang akan dilaluinya menjadi pilihan utama, dilenkapi pula dengan kondisi eksisting trotoar sebelah timur koridor Jalan Pemuda Kota Magelang yang lengkap dengan street furniture yang mendukung kenyamanan untuk beraktivitas berjalan kaki;

- Trotoar yang lebar menjadi pilihan kedua selanjutnya dari pedestrian untuk melakukan aktivitas berjalannya pada trotoar, dan itu dimiliki oleh trotoar di sebelah timur koridor Jalan Pemuda Kota Magelang. Kondisi trotoar yang lebar membuat pedestrian (pejalan kaki) bebas bergerak di trotoar tersebut.

Kondisi licin yang disebabkan karena material yang terbuat dari keramik serta kondisi tidak aman karena adanya pengguna lain (sepeda, becak, sepeda motor dan pedagang kaki lima), tetap membuat pedestrian memilih berjalan di trortoar sebelah timur, hal ini dikarenakan pedestrian masih merasa dapat bergerak bebas dengan kondisi trotoar yang lebar sehingga dapat terhindar dari gangguan-gangguan pengguna lain.

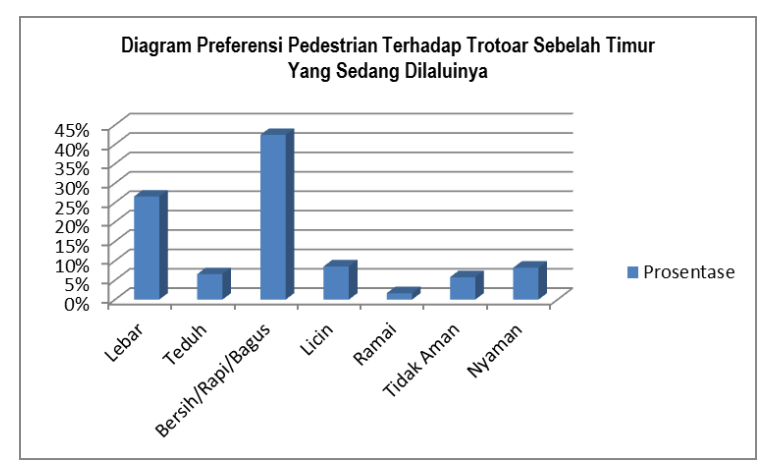

Gambar Diagram Preferensi Pedestrian Terhadap Trotoar Sebelah Timur Yang Sedang Dilalui Di Koridor Jl. Pemuda Kota Magelang Sumber: Hasil Survey 


\section{Tanggapan Pedestrian Terhadap Trotoar Sebelah Barat Yang Dilewati}

Tanggapan Pedestrian terhadap trotoar sebelah barat yang dilewati menunjukkan bahwa:

- Pedestrian (pejalan kaki) masih memilih kondisi trotoar yang bersih dan rapi, lebar serta nyaman terhadap jalur pedestrian yang akan dilaluinya menjadi pilihan utama;

- Kondisi trotoar yang tidak licin menjadi pilihan kedua di trotoar sebelah barat, karena material yang terbuat dari paving block, dan ini menjadi pilihan sebagian pejalan kaki karena rasa aman dalam melakukan aktivitas berjalan kaki;

Kondisi trotoar yang kurang bersih trotoar, trotoar tidak aman karena dekat dengan pergerakan lalu lintas kendaraan bermotor, merupakan pilihan dengan prosentase rendah yang menjadi pilihan pedestrian (pejalan kaki) dalam menggunakan trotoar di sebelah barat.

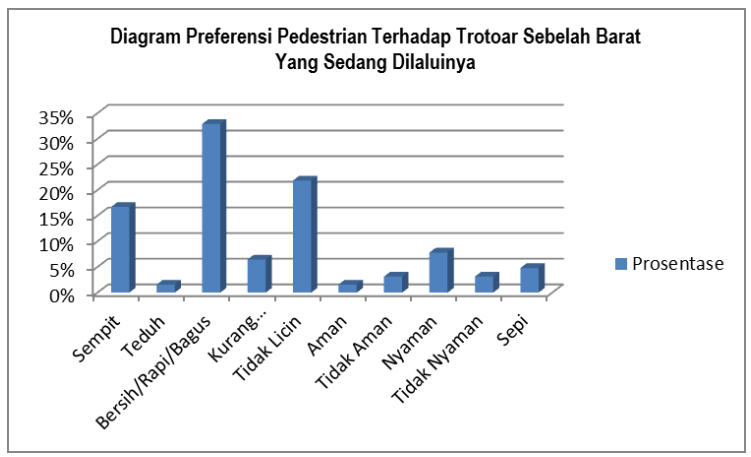

Gambar Diagram Preferensi Pedestrian Terhadap Trotoar Sebelah Barat Yang Sedang Dilalui Di Koridor Jl. Pemuda Kota Magelang Sumber: Hasil Survey

\section{Tanggapan Pedestrian Terhadap Pilihan Trotoar Di Koridor Jalan Pemuda Kota Magelang}

\section{Pedestrian Yang Berjalan Di Trotoar Sebelah Timur}

Dari hasil data yang didapat menunjukkan bahwa pedestrian (pejalan kaki) lebih memilih trotoar di sebelah timur dari pada di sebelah barat saat melakukan aktifitas berjalan kaki di sepanjang koridor Jalan Pemuda Kota Magelang.

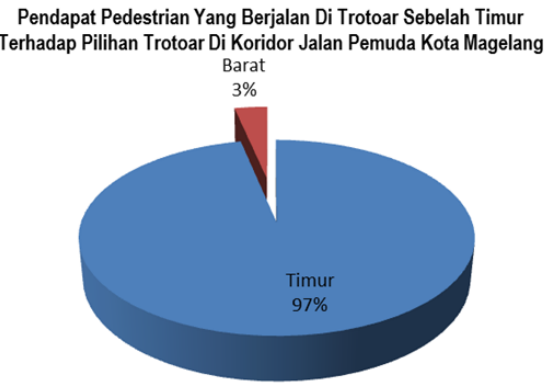

Pilihan pedestrian dalam memanfaatkan trotoar sisi sebelah timur dilakukan dengan pertimbangan antara lain:

\begin{tabular}{|c|l|c|}
\hline Urutan Pilihan & \multicolumn{1}{|c|}{ Pendapat Responden } & Prosentase \\
\hline 1 & Lebar & $32 \%$ \\
\hline 2 & Nyaman & $19 \%$ \\
\hline 3 & Dekat Tempat Parkir & $11 \%$ \\
\hline 4 & Akses Sirkulasi Mudah & $10 \%$ \\
\hline 5 & Tidak Licin & $7 \%$ \\
\hline 6 & Lebih Banyak Toko Buka & $6 \%$ \\
\hline 7 & Aman & $5 \%$ \\
\hline 8 & Bersih/Rapi/Bagus & $4 \%$ \\
\hline 9 & Kebiasaaan & $4 \%$ \\
\hline 10 & Teduh & $2 \%$ \\
\hline 11 & Sepi & $1 \%$ \\
\hline
\end{tabular}

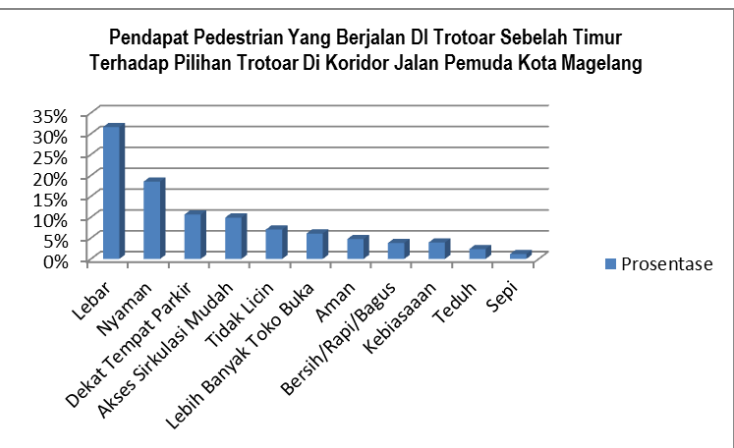

Pedestrian Yang Berjalan Di Trotoar Sebelah Barat

Dari hasil data yang didapat menunjukkan bahwa pilihan pedestrian (pejalan kaki) berjalan di sepanjang trotoar di sebelah barat adalah sebagai berikut:

Diagram Preferensi Terhadap Trotoar Di Koridor Jalan Pemuda Berdasarkan Pedestrian Yang Berjalan Di Trotoar Sebelah Barat
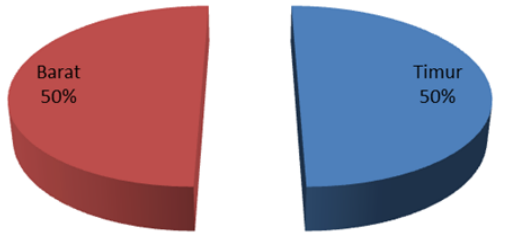
Pilihan pedestrian dalam memanfaatkan trotoar sisi sebelah barat dilakukan dengan pertimbangan antara lain $(50 \%$ Pedestrian Memilih Trotoar Sebelah Timur):

\begin{tabular}{|c|l|c|}
\hline Urutan Pilihan & \multicolumn{1}{|c|}{ Pendapat Responden } & Prosentase \\
\hline 1 & Lebar & $24 \%$ \\
\hline 2 & Nyaman & $7 \%$ \\
\hline 3 & Dekat Tempat Parkir & $6 \%$ \\
\hline 4 & Lebih Banyak Toko Buka & $6 \%$ \\
\hline 5 & Akses Sirkulasi Mudah & $5 \%$ \\
\hline 6 & Teduh & $3 \%$ \\
\hline \multicolumn{2}{|c}{} \\
\hline
\end{tabular}

Pendapat Pedestrian Yang Berjalan DI Trotoar Sebelah Barat Terhadap Pilihan Trotoar Di Koridor Jalan Pemuda Kota Magelan (50\% Pedestrian Memilih Trotoar Sebelah Timur)

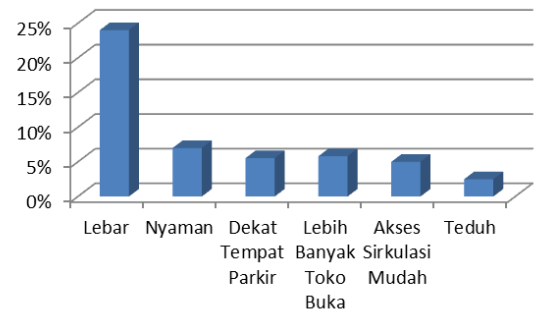

Prosentase

Pilihan pedestrian dalam memanfaatkan trotoar sisi sebelah barat dilakukan dengan pertimbangan antara lain (50\% Pedestrian Memilih Trotoar Sebelah Timur):

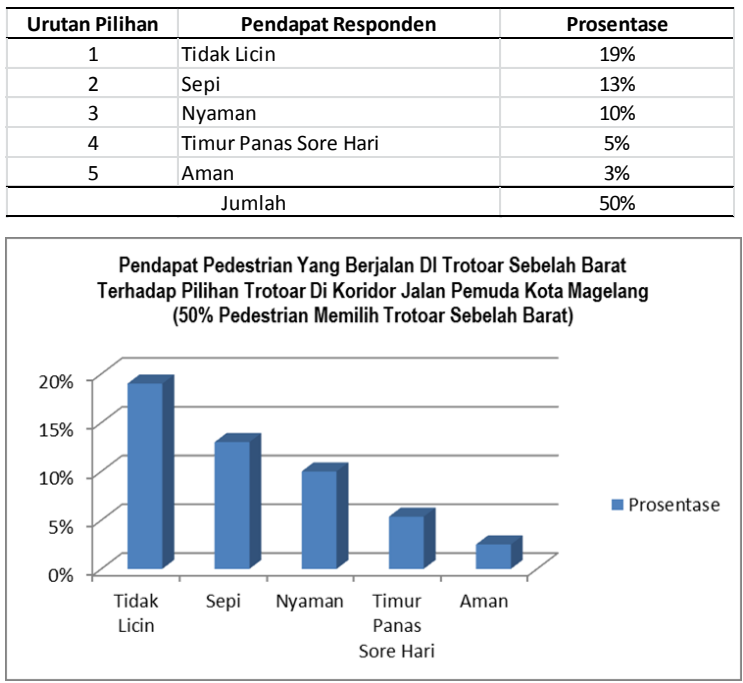

\section{SIMPULAN}

Dari hasil hasil Studi yang telah dilakukan pada bab sebelumnya, maka diperoleh hasil kesimpulan yang berkaitan dengan preferensi pedestrian (pejalan kaki) menggunakan trotoar sebagai aktifitas berjalan kaki di koridor Jalan Pemuda Kota Magelang.

1. Pejalan kaki lebih memilih berjalan di trotoar disisi sebelah timur koridor Jalan Pemuda Kota Magelang dengan pertimbangan karena: kodisi jalan yang lebar, nyaman untuk berjalan kaki, dekat dengan tempat parkir sehingga mudah mencapai toko terdekat, trotoar di sisi sebelah timur lebih baanyak toko yang buka sehingga banyak alternatif dalam memilih toko, akses sirkulasi yang mudah dan trotoar lebih teduh karena lebih banyak pohon-pohon disepanjang trotoar tersebut.

2. Pejalan kaki tetap memilih berjalan kaki untuk aktivitas pergerakan sirkulasinya di trotoar sebelah barat dengan pertimbangan, karena: trotoar di sisi sebelah barat tidak licin karena material yang dipasang masih dari paving block dari pada trotoar di sisi sebelah timur yang menggunakan material keramik, trotoar cenderung sepi, nyaman untuk berjalan kaki, berjalan di trotoar sisi sebelah barat lebih teduh pada sore hari, aman untuk berjalan kaki.

3. Kedekatan dengan tempat parkir juga menjadi pilihan para pedestrian (pejalan kaki) lebih memilih trotoar sebelah timur, hal tersebut didukung pula dengan banyaknya pilihan toko yang ada di sisi timur koridor.

4. Akses sirkulasi yang mudah menuju ke arah utara yaitu Alun-alun maupun ke arah selatan yaitu Pasar Rejowinangun, membuat pedestrian merasa aman dalam melakukan pergerakan sirkulasinya, tanpa perlu menyeberang di jalur cepat Jalan Pemuda.

5. Meskipun material trotoar terbuat dari keramik kasar bagi pedestrian masih merasa aman dan tidak mengganggu dalam melakukan pergerakan sirkulasi di trotoar tersebut, meskipun bagi sebagian pengguna dihindari karena licin.

6. Kondisi trotoar yang banyak vegetasi dan properti lainnya menjadi perhatian pedestrian dalam menggunakan trotoar sebelah timur, karena dirasakan berjalan di trotoar tersebut terasa teduh, bersih dan rapi, sehingga semakin nyaman untuk digunakan berjalan kaki.

7. Kondisi pengguna lain yang turut memanfaatkan trotoar bagi pejalan kaki masih bisa diantisipasi dengan lebar trotoar yang cukup besar, sehingga bagi pejalan kaki rasa aman dan nyaman masih bisa diperoleh.

8. Pemilihan berjalan di trotoar sebelah barat bagi sebagian pedestrian (pejalan kaki) 
karena kondisi trotoar yang terbuat dari material paving block, sehingga tidak licin baik pada waktu hujan maupun panas membuat pedestrian merasa aman berjalan di trotoar tersebut.

9. Bagi sebagian pengguna trotoar di sebelah barat merasa nyaman berjalan di trtoar tersebut karena kondisi yang sepi dan tidak terganggu oleh pengguna lain, sehingga pergerakan sirkulasinya lebih bebas, hal ini terutama dipilih oleh penjual makanan tenongan (gendongan).

10.Letak jalur pedestrian yang harus ditempuh dengan menyeberang jalan utama yang relatif ramai, membuat pejalan kaki yang tidak memanfaatkan trotoar sebelah barat.

11.Jalur pedestrian yang langsung berdampingan dengan jalur cepat memberikan rasa tidak aman bagi pejalan kaki yang melakukan aktifitasnya di trotoar sebelah barat.

\section{DAFTAR PUSTAKA}

Brambilla, Roberto, 1977, For Pedestrians Only, Watson-Guptill Pubns.

Carr, Stephen, cs, 1992 Public Space, Cambridge University Press, Cambridge.

Darmawan, Edy, 2003, Teori Dan Kajian Ruang Publik Kota, Badan Penerbit Universitas Diponegoro, Semarang.

Darmawan, Edy, 2005, Analisa Ruang Publik Arsitektur Kota, Badan Penerbit Universitas Diponegoro, Semarang

Echols, John M, Shadily, Hasan, 2003, Kamus Indonesia Inggris, Gramedia Pustaka Utama, Jakarta.

Hall, Edward T, 1966, The Hidden Dimensian, Doubleday and Company Inc, New York.

Lang, Jon, 1987, Creating Architectural Theory, Van Nostrand Reinhold Company Inc., New York.

Rapoport, Amos, 1977, Human Aspect of Urban Form, Paragon Press, New York.

Rapoport, Amos, 1979, Development, Culture Change and Supportive Design (terjemahan).

Rubenstein, Harvey, 1992, Pedestrian Malls, Streetscapes and Urban Spaces, John Wiley \& Sons Inc., New York.

Sarwono, Sarlito Wirawan, 1992, Psikologi Lingkungan, PT. Grasindo, Jakarta.
Spreiregen, Paul D., 1965, Urban Design: The Architecture of Town and Cities, Mc. Graw-Hill Book Company USA.

Haryadi, Setiawan, B, 1995, Arsitektur Lingkungan dan Perilaku, Direktort Jenderal Pendidikan Tinggi, Departemen Pendidikan dan Kebudayaan.

Shirvani, Hamid, 1985, The Urban Design Process, Van Nostrand Reinhold Co., New York.

Tim Reality, 2008, Kamus Terbaru Bahasa Indonesia, Reality Publisher, Surabaya.

Utermann, RK, 1984, Acomodation The Pedestrian, Van Nostrand Reinhold Company, New York.

Weisman, J, 1981, Modelling Environment Behavior System, Journal of Man Environment Relation.

Zeizel, John, 1975, Inquiry by Desgn Tools for Environment Behavior Research, Cambridge University Press, Cambridge. 